\title{
The multicultural and multi-religious Norwegian kindergarten
}

\author{
Kari Krogstad ${ }^{1}$
}

Published online: 17 May 2016

(C) The Author(s) 2016. This article is published with open access at Springerlink.com

\begin{abstract}
This paper investigates the concept of "the multicultural" as it informs the national guidelines for Norwegian kindergarten teacher education (KTE). According to these guidelines, KTE students should gain multicultural knowledge that encompasses exposure to different religious beliefs. The results of an empirical study on multi-religious kindergartens in Norway serve as the context for this analysis, which identifies discrepancies between the multicultural ideal suggested in the guidelines and the realities described by pedagogues in kindergartens. Underlying this analysis is an awareness of the impact of different discourses on our understanding of multiculturalism. Anna-Malin Karlsson's study focusing on the role of context in discourse and Susanne V. Knudsen's work on the power of definition will be instructive here. The meanings of the term "multicultural" in different national and local contexts will inform this study, which concludes with the suggestion that the educational system-including the government, KTE, academic staff, and pedagogues in practical trainee kindergartens-must work together to contextualize and define the multicultural kindergarten.
\end{abstract}

Keywords Norwegian kindergarten teacher education · Practical trainee kindergartens · Multicultural $\cdot$ Cultural diversity $\cdot$ Multi-religious $\cdot$ Religion

\section{Introduction}

In this paper I will outline what the national guidelines for Norwegian Kindergarten teacher education (KTE) have to say concerning the concept of "the multicultural", ${ }^{\text {and I }}$ will consider how local program plans perceive and interpret these guidelines, with

1 "The multicultural" is throughout this paper a translation of the Norwegian word "det flerkulturelle".

Kari Krogstad

kari.krogstad@hit.no

1 University College of Southeast Norway, Postboks 235, 3603 Kongsberg, Norway 
particular focus on the academic staff at one higher education institution. My other data source is a series of interviews with pedagogues in practical trainee kindergartens about their experiences in multicultural and multi-religious kindergartens. ${ }^{2}$

Some previous research has focused on multicultural and multi-religious kindergartens and KTE in Europe and Nordic countries. For example, Schweitzer et al. (2011) have written on the topic from the German perspective by investigated how kindergarten personnel work with children from different cultural and religious backgrounds. Another study explores religious education in the KTE in Germany, Nordic countries and Austria (Schweitzer and Biesinger 2015), while Sturla Sagberg has examined related matters in Norway (2011, 2012, 2013) and also conducted a comparative study (2003). Saila Poulter et al. (2015) have examined different perspectives on the concepts of worldview and religion in the context of multicultural education. And Kuusisto and Lamminmäki-Vartia (2012) have looked at the moral foundation of the Finnish KTE and compared it with empirical findings from kindergartens in Finland.

My approach is different from previous research because I use discourse analysis. Using a context-specific linguistic approach that looks at how, by whom, and according to which discursive practices particular terms are used and construed, I will consider the term "the multicultural" within two different contexts: Norwegian KTE and practical trainee kindergartens. My material is analyzed based on which discourses that exist regarding the term "the multicultural" in national documents, among academic staff in one teacher training program, and among kindergarten pedagogues. The analysis will be based on two works in particular: that of the sociolinguist Karlsson (2010), who focused on the role of context in discourse; and research by Knudsen (2010) that calls attention to the power of definition in educational texts. This theoretical framework will allow for a discussion of the different discourses concerning the multicultural that result from the different contexts and power structures that give rise to how multicultural and multi-religious kindergartens are viewed and defined.

The limitations of this study's design have to do with the limited amount of information upon which the analysis is based: written statements by academic staff in one KTE program and interviews with kindergarten pedagogues. The data are not quantitatively large enough to serve as the basis for far-reaching generalizations. My investigation will therefore focus on providing insights into what kindergarten pedagogues find challenging about multicultural kindergartens. What this study examines are the perceptions described and summarized by the informants; a full account of real practices and a comprehensive study of the views of KTE students, parents, and kindergarten personnel will require a broad-based approach that is beyond the scope of this study.

\subsection{Background}

In 2013 KTE replaced the former preschool teacher education [PTE] in Norway. KTE is founded on two main documents: Regulations for the national curriculum for kindergarten teacher education [Regulations] (2012), and National guidelines for kindergarten teacher education [Guidelines] (2012). The main change from PTE to KTE is that instead of covering

\footnotetext{
${ }^{2}$ Practical trainee kindergartens have agreements with KTEs to have students in training complete their practicums there as part of their studies. The interviews used in this study with pedagogues in twelve practical trainee kindergartens are from a research project I conducted with K.-M. W. Hidle, Minority religions in kindergartens (Krogstad and Hidle 2015). The twelve pedagogues were selected to interview because they had Muslim children represented in their kindergarten.
} 
separate subjects, as in PTE, KTE focuses on six fields of knowledge that encompass two or more subjects and devotes special attention to multicultural perspectives. ${ }^{3}$

According to the KTE Regulations (2012), students for kindergarten teacher positions "shall have knowledge about the different conditions under which children are raised and be aware of their different background and development in a society characterized by linguistic, social, religious, and cultural diversity" (p. 2, italics added). The students shall also "have general competence in drawing on their global, national, regional, local and multicultural perspectives, characterized by respect and tolerance, in their work in kindergarten" (p. 3, italics added). Below I will outline the meanings of the two terms used in the Regulations: cultural diversity and the multicultural.

All kindergartens in Norway must work according to the Framework Plan for the Content and Tasks of Kindergartens [Framework Plan] (2011), established by the Ministry of Education and Research. The first edition came out in 2006 and was revised in 2011. The Framework Plan provides guidelines for the values, content, and tasks taught in seven subjects. It describes cultural diversity in this way:

In addition to the majority population, Norwegian society consists of Indigenous Sámi people, national minorities and minorities with immigrant backgrounds. Because of geographic mobility and increasing internationalization, Norwegian society is far more diverse than it was in the past. There are now many ways of being Norwegian. This cultural diversity shall be reflected in kindergartens. Social, ethnic, cultural, religious, linguistic and economic differences in the population mean that children come to kindergarten with different experiences. Kindergartens shall support children on the basis of their own cultural and individual circumstances. (2011, p. 7)

The Framework Plan mentions the Sámi people, and the Remark on the regulations for the national curriculum for kindergarten teacher education [Remark] (2013) specifies that cultural diversity "includes the Sámi people" (p. 3). The Framework Plan states that the "population in Norway is characterized by a linguistic, cultural and religious diversity that enriches and strengthens the community in the kindergarten" (2011, p. 30). To support the kindergarten's work in implementing the Framework Plan, the Norwegian government has published several pamphlets. One of these, the Pamphlet on linguistic and cultural diversity [Pamphlet] (Gjervan 2006), defines diversity in the kindergarten as including language, culture, and religion.

In the Framework Plan (2011) the term multicultural is used just once. In the introduction to the subject "Ethics, religion and philosophy", it states: "Norway is today a multi-religious and multicultural society" (2011, p. 20). The term "multi-religious" is interesting because the Framework Plan references Humanism and only one religion, Christianity. Islam is the largest quantified minority religion in Norway, but it goes unmentioned in both the national guidelines and the Framework Plan. One of the fields of knowledge in KTE is "Society, religion, worldviews and ethics" [SRLE]. ${ }^{4}$ According to the Guidelines, the students shall have knowledge of "the Christian faith and cultural heritage, the other world religions, different worldviews and philosophy". This means that it is up to each KTE to decide what "other world religions" exactly means. This study's informants from practical trainee kindergartens generally appear to view this expression as a reference to Muslims.

\footnotetext{
${ }^{3}$ KTE is for three years and consists of 180 credits. The six fields of knowledge, each constituting 20 credits, and the bachelor's thesis (30 credits) are compulsory; the rest (30 credits) are optional.

${ }^{4}$ SRLE is the Norwegian abbreviation.
} 


\subsection{Cultural diversity, the multicultural and multi-religious}

I will refer to cultural diversity in terms of a multitude of religions and worldviews. One way to quantify this is the number of adherents within a society. In 2014, in Norway $74.3 \%$ of the population consisted of members of the Norwegian Church, $11.5 \%$ consisted of adherents to different religions and worldviews, and the remaining $14.2 \%$ did not adhere to a particular religion (Statistics Norway 2014, 2015). ${ }^{5}$

I place "the multicultural" in quotation marks to stress that it is distinctively different from the concept of multiculturalism. Multiculturalism can be both a descriptive concept-denoting a society composed of different cultural groups-and a normative concept used to confirm and promote diversity as a model for human life. In the latter sense, the idea of multiculturalism serves to preserve and accept cultural differences (e.g., celebrating the religious and cultural heritage of Muslim groups [Modood 2007]). Multiculturalism can denote an active policy approach: for example, as Berry (2013) notes, in the Canadian context two features of multiculturalism (diversity and equity) are central to certain policies (p. 665). The point here is not so much to discuss multiculturalism but rather to indicate that in the context at hand (KTE), the term "multicultural" is a slippery one. In Norway's official documents about kindergartens, the concept "the multicultural" is used in conjunction with government policy concerning the integration of immigrants from outside Europe (e.g., White Paper 2012). As I have indicated in a previous analysis of official documents regarding Norwegian kindergartens, the government largely ignores religion in discussions of the multicultural and emphasizes instead cultural diversity and the minority language backgrounds of kindergarten children and their parents (Krogstad 2015).

In 2006 the Department of Education introduced a view on the multicultural kindergarten that was resource-orientated, in accordance with the Pamphlet. Otterstad and Andersen (2012), Norwegian researchers who work on early childhood education, argue that both documents - the Framework Plan and the Pamphlet-make multicultural perspectives the starting point for pedagogic theory and practice. The authors point out that the two documents leave open the question of what kind of theoretical framework should be used in practice, and they leave the matter of theoretical perspective to individual practitioners (p. 10). My question is how the multicultural is defined and perceived by educators and practitioners. Guidelines about creating multicultural and multi-religious kindergartens fail to appreciate the whole reality of the kindergarten setting, and because of that it is important that academic staff members have knowledge about how kindergarten pedagogues experience the reality in kindergartens. The KTE and kindergartens themselves must together contextualize the multicultural kindergarten in unlike local contexts. In this regard searching for discourses can shed light to see how the KTE and kindergartens perceive the multicultural kindergarten.

\section{Method}

The national guidelines for KTE inform local program plans in each institution of higher education with a KTE program. My research has entailed analyzing what the Guidelines say about multicultural perspectives in different fields of knowledge and comparing these statements with program plans at one KTE institution. I began my work by sending out an e-mail to a total of 33 persons who were teaching at this institution; I received 26 answers.

\footnotetext{
5 Of the 11.5 percent, 6.6 percent adhere to Christianity and 2.6 percent to Islam.
} 
The e-mail laid out the national guidelines and asked the respondents how these guidelines compared to local plans that impacted them. They were then asked to comment upon the differences between the Guidelines and how aspects of the educational plans were realized in the institution where they worked. For example, the national guidelines for one field of knowledge, "Nature, health and movement" [NHB], stipulate that the students should gain knowledge about "nature, bodily play, diet and health in a multicultural perspective", but the local plan does not mention this. Those who teach NHB were asked to explain why this is the case and to say whether they focused on a multicultural perspective in their lectures in kindergarten teacher training programs.

The interviews with pedagogic personnel were conducted in twelve kindergartens that have agreements with two higher education institutions to be joint partners as practical trainee kindergartens. The informants were asked: "What do you think KTE should address concerning multicultural issues in a kindergarten setting?"

\subsection{Text analysis of the guidelines and the kindergarten as a context}

The Guidelines (2012) can be classified as having both pedagogical and ideological aims. They follow Knudsen and Bente Aamotsbakken's definition of "institutionally limited texts" in that they consider "the context as a place for use" along with "the intentions of users and authors or senders, as well as relations between objects and users" (2010, p. 15). The ideological and political context for the KTE guidelines extends beyond the classroom because the Guidelines outline the premises underlying the content for kindergarten instruction and therefore influence how kindergarten personnel work with children and their parents.

Karlsson's research on literacy practices and communication in institutional settings is useful here $(2011,2014)$. Karlsson's research looks at the relations between texts and what is outside of those texts (i.e., contexts). Referring to Norman Fairclough (1995), whose model illustrates the different levels in a critical discourse practice surrounding social cultural practice (2010, p. 163), Karlsson claims that if we start at "the other end" with social practice, as a way of understanding texts and their functions, the communication picture can look different. Nevertheless, she does point out that decentralizing the place of the text in the communicative act "does not mean that it isn't worth studying as a text" (p. 164). The national guidelines are not directly relevant to kindergarten pedagogues practicing their profession, but the guidelines should be of interest to them because in 2016 the first class of students will graduate from KTE with theoretical knowledge about the multicultural kindergarten. The Guidelines should not at least be interesting for the practical trainee kindergartens that have students.

Theory about text linguistic or text grammar are "concerned about to see the texts as text in a context" (Aamotsbakken 2010, p. 76). The national guidelines, which are central for a multicultural kindergarten context, must also relate to how kindergarten pedagogues experience and understand their own kindergartens as limited contexts. Staff members come from a variety of ethnic and religious backgrounds. As Poulter et al. (2015) states, the Western standpoint is not shared by all Westerners, and there are differences between individuals within communities and societies (p. 13). Each individual represents a particular, unique worldview, and kindergartens in Norway are diverse when it comes to representing the cultures and worldviews of staff members, parents, and children. Kindergarten personnel must also see their kindergartens in relation to the wider local community and the nation. 


\subsection{Discourses and definitions}

The term "discourse" is defined here as a certain way of speaking about and understanding the world (Aamotsbakken 2010) or meanings (Karlsson 2010). It is a mode of organizing knowledge or experience that is rooted in language and its concrete contexts. The term comes from the Latin "discursus", which derives from "discurrere", which means to run back and forth (Knudsen 2010, p. 155). In L'ordre du Discours (1970), the philosopher and historian of ideas Michel Foucault defined discourse in relation to the power of defining.

The way different discourses have constructed "the multicultural" has been the subject of a study that looked at one primary schoolteacher education program in Norway (Fylkesnes 2011). Its findings show that the multicultural "generally is constructed as an otherness, as the non-Norwegian and understood as not part of the Norwegian identity" (p. 121). A study of Finnish teacher education reached a similar conclusion: "multicultural/intercultural education tends to deal solely with the foreign other" (Dervin 2015, p. 72). A similar perspective is found in Norway's national guidelines, where the multicultural perspective is conceived as something that is added to a presumably homogenous Norwegian perspective: in the field of knowledge designated as "Language, text and mathematics" [STM], the Guidelines state that students shall have knowledge "about children's mathematic development, children's oral and written language and linguistic development, also in a multi-linguistic and multicultural perspective" (italics added). This language can be interpreted as meaning that the multicultural refers to all cultures other than that of the majority Norwegian population. The problem is that the majority is not a homogenous group, but rather represents a wide array of different and unique persons. In this regard the Guidelines can be seen as "Othering" individuals and groups in the name of acknowledging multicultural perspectives (Poulter et al. 2015, p. 3).

\section{Findings}

I have organized the results of this study into four sections: (1) national guidelines for KTE; (2) local program plans in one institution of higher education; (3) written statements from academic staff at the same institution; and (4) interviews with pedagogues in kindergartens.

\subsection{The national guidelines}

The national guidelines describe the desired learning outcomes for early education students as they relate to exposure to multicultural perspectives and cultural diversity in five of the six compulsory fields of knowledge: Art, culture and creativity [KKK]; STM; NHB; SRLE; and Children's development, play and learning [BULL] (See Table 1). ${ }^{6}$

Knowledge about the Sámi is mentioned in all five fields: particularly noteworthy is the stipulation that students in BULL are required to have knowledge about "Sámi childrearing customs and norms".

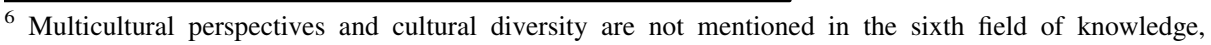
Management, collaboration and development.
} 
Table 1 National guidelines for KTE (2012)

\begin{tabular}{ll}
\hline Term & Desired learning outcomes for kindergarten education students \\
\hline $\begin{array}{l}\text { Multicultural } \\
\text { perspectives }\end{array}$ & $\begin{array}{c}\text { Have knowledge about children's mathematical development, children's oral and } \\
\text { written language development, including from multi-linguistic and multicultural } \\
\text { perspectives (STM) } \\
\text { Have knowledge about children's culture and culture heritagefrom a multicultural } \\
\text { perspective (KKK) } \\
\text { Have general competence in incorporating multicultural perspectives in creative } \\
\text { activities (KKK) } \\
\text { Have knowledge about nature, physical play, diet, and health from a multicultural } \\
\text { perspective (NHB) } \\
\text { Have knowledge about the basic values of kindergarten and what they imply in } \\
\text { practice within a multicultural society (SRLE) } \\
\text { Have the needed skills for analyzing and reflecting upon basic questions concerning } \\
\text { social and cultural diversity; have ability to use these skills as a resource in } \\
\text { pedagogic work with children, in collaboration with parents (BULL) } \\
\text { Have the skills to promote cultural diversity in kindergartens when imparting } \\
\text { knowledge through texts (STM) } \\
\text { Have general competence to analyze and engage in critical reflection about gender, } \\
\text { equal opportunities, equality, cultural diversity, routines in kindergarten, diet and } \\
\text { activity as central qualities of life and factors that promote health in kindergarten } \\
\text { (NHB) }\end{array}$ \\
Cultural diversity
\end{tabular}

Table 2 Local program plans (2014-2015)

\begin{tabular}{|c|c|}
\hline Term & Desired learning outcomes for kindergarten education students \\
\hline $\begin{array}{l}\text { Multicultural } \\
\text { perspectives }\end{array}$ & $\begin{array}{l}\text { Themes relating to diversity, multicultural and multilingual children are addressed } \\
\text { in connection to the theme "Pedagogic leadership" (BULL) The students are } \\
\text { aware of multicultural perspectives in arranging creative meetings, and the } \\
\text { students understand the possibilities for creative activities that promote a } \\
\text { multicultural and equal society (KKK) }\end{array}$ \\
\hline Cultural diversity & $\begin{array}{l}\text { Students shall have competence in physical activity in relation to the development of } \\
\text { the society and different cultures (NHB) }\end{array}$ \\
\hline
\end{tabular}

\subsection{Local program plans}

All teachers are obliged to have a multicultural perspective in their teaching with reference to the Regulations (2012). Table 2 displays how the national guidelines are elaborated in the local plans for one institution of higher education (See Table 2).

The Sámi are mentioned only in local plans for SRLE, but given the national guidelines, the Sámi should have also been mentioned in BULL, NHB, STM, and KKK.

\subsection{Academic staff}

Statements by the academic staff at the institution of higher education in this study explain the possible gap or lack of coherence between the national guidelines and local program plans. One informant who teaches in KKK writes: "The field of knowledge scope, and the teacher's resources to preparation is decisive for what we can carry out". This informant 
also states that the goals in the national guidelines are too extensive and are written "by those who do not know the framing conditions for institutions of higher education". The statement about limited resources and framework conditions resembles many of the written answers from the academic staff. Another view comes from an informant who teaches in SRLE: "There is no requirement that local program plans include a copy of the national guidelines".

On the subjects of multicultural perspectives and cultural diversity, the academic staff members give varied answers. One informant who teaches pedagogy in STM, BULL, and SRLE writes: "Cultural diversity is a resource, and students' ability to demonstrate fundamental tolerance, interest, and respect for children regardless of background is an ongoing theme in all the lectures. This is also seen in connection to cooperation with parents". This statement resembles the words in both the Regulations and the Guidelines. Another informant who teaches pedagogy writes:

I talk about diversity and multicultural and multilingual children on a general basis, for instance on the subject of adaptive training, children with special needs, and children's individual conditions for learning ability. I always draw upon examples, and diversity/differences in language and culture are drawn in, but on a general basis.

What the informant means by "on a general basis" is not elaborated. One informant in STM writes: "We teach using different numeric systems and methods for measuring from different cultures; it's a part of the fundamental approach to learning in mathematics, but cross-cultural aspects of learning should be more explicit in the local program plan".

Informants who teach in NHB write that they teach about multicultural diets (according to the national guidelines, "diet and health in a multicultural perspective") in connection to children with special needs, whether those dietary needs are grounded in religious belief or food intolerance. They also have a theme called "Health and diet", where the students can write about different topics-for instance, multicultural diets.

The academic staff members reflect diversity and multicultural perspectives in their lectures. Most of the informants say that they teach about diversity in general terms, without necessarily addressing the subjects being taught in connection to language, culture, and religion - with the notable exception of SRLE, which deals directly with religion and culture. The reason for this is because resources are limited, but also because many of the teachers feel that the national guidelines are nonbinding. Despite the fact that the topic does not appear in the local plan, many of the informants state in their responses that they teach about the Sámi along the lines outlined in the national guidelines.

\subsection{Pedagogues in kindergartens}

In the interviews with twelve pedagogues, we asked them: "What do you think KTE should address concerning multicultural issues in a kindergarten setting?" They answered by giving us examples of challenges they faced. The informants defined and understood the multicultural kindergarten as a place where Muslims are represented. They gave answers along the following lines: "We have a lot of multicultural elements because we have children that are Muslims." Or: "We have many Muslim children in our kindergarten, so there is a lot of diversity."

The informants were focused on cooperation with the parents of children from minority groups, and they considered it important to show signs of "humbleness and respect toward 
their backgrounds", as one said. Another informant pointed out: "We have to respect the parents, and their culture and religion, and it is important, so that the children become integrated, that they learn Norwegian well and become integrated in the society".

The informants had experienced conflicts between ethnic groups (e.g., Kurds and Turks), and these conflicts had entered the realm of the kindergarten. One informant said these issues sometimes led to problems in everyday life, when parents didn't want their children to play with one another or appear in the same photograph because of conflicts in their homelands. Another informant explained that some of the families in their kindergarten are refugees "who may be at war with each other in their homelands". Because of these situations, the kindergartens were aware of these "differences with potential difficulties".

The last topic the informants talked about was Muslim child-rearing norms and traditions. One informant said: "When we have child welfare cases, interventions sometimes fail, and that's due to different views on how to raise children." The same informant contrasted Muslim attitudes toward child-rearing with the Norwegian view "that children should learn to be independent and, for example, put on their own clothes and feed themselves, and that girls and boys should be equal." These notions were unfamiliar to some parents due to their cultural and religious backgrounds. Another informant said that parents from Somalia required extra work on the part of pedagogues:

They have a totally different way of raising children. I tell them that it is important that they set boundaries for their children. The children are given a great deal of freedom until they reach puberty, and then they are subject to stringent controls. It is a very different way of thinking, and it is very difficult. And this is due to culture.

A third informant felt that knowledge about the multicultural kindergarten was tied to knowledge about human beings: "We need to understand how other cultures think about child-rearing. In many countries these customs are tied up with religion." Further, the informant said: "In our kindergarten we have a lot of child welfare cases and parents are maybe emotionally damaged. We can meet these families and their children in a totally different manner if we know more about how religion informs all aspects of their life, including child-rearing."

The informants all agree that KTE should give students more formal knowledge about how different cultures and religions impact everyday life in kindergartens.

\section{Discussion}

We see from our findings that there is almost no consensus about what the multicultural kindergarten means. Its influence ranges from concrete perspectives informing language and mathematics in the national guidelines, to attitudes toward creative and physical activities in the local program plans, to general descriptions from the academic staff, to concrete challenges in kindergartens having to do with child-rearing norms in non-Norwegian cultures. One way to understand these different discourses about the multicultural kindergarten is by analyzing more carefully the different ideas of the multicultural and the contexts in which they arise.

Karlsson (2010) claims that research on texts is essentially about context. The intended context for the national guidelines is in KTE among the academic staff, but also in practical training kindergartens, among the staff, trainees, children, and their families. In this regard 
the text is important for both the educational system and the kindergartens. Local program plans are geared toward unique contexts, and even if academic staff members work closely together with pedagogues in practical training kindergartens, their interpretations and perceptions of multicultural issues may be entirely different.

Notions such as "the multicultural" and "cultural diversity" are ambiguous unless defined in relation to something. The Guidelines connect the multicultural with concrete knowledge and skills that students are required to master: for instance, children's mathematical development in STM includes a multicultural component. But even if a multicultural perspective is added, a consequence can be that "interpretations of a word such as 'the multicultural' may be filled with different content and it may therefore mean different things to different people" (Fylkesnes 2011, p. 3). This can seem to be the case when one of the academic staff, who teaches in pedagogy, claims to "talk about multicultural children on a general basis". The pedagogues in kindergartens, on the other hand, mention concrete challenges in a multicultural reality, like ethnic conflicts and differing views on child-rearing between staff and parents.

Foucault (1970) defined discourse in relation to power, and specifically the question of who gets to define what. In the Guidelines some issues are not mentioned, such as differences in child-rearing practices due to parents' religious and/or cultural backgrounds. The Framework Plan (2011) says that the kindergarten must take children's backgrounds into consideration, and the Regulations (2012) state that students at KTE require knowledge of those backgrounds. This means that the academic staff must define the cultural, linguistic, and religious differences that the students are likely to encounter in reality. The academic staff's interpretations of the Guidelines don't express the reality when the local program plans specify that the students should be aware of multicultural perspectives in arranging creative activities, or that they should have cultural competence about how physical activity relates to the norms of different cultures. This academic staff's role in training students to deal with the issues surrounding the multicultural is an example of the power of definition.

Knudsen (2010) points out that Foucault's notion of discourse leads us to investigate who has the power to define (pedagogic) texts. I can question what is behind political discourses, for instance why the Guidelines emphasis mathematic and impart of texts, but nothing about religious and/or cultural instigated child-rearing as the informants from kindergartens where concerned about. The national guidelines require students to acquire knowledge about Sámi child-rearing practices. I question why the Guidelines not require the same kind of knowledge about cultural practices among people of other cultures and religions (e.g., Islam or Christianity).

Academic staffs have the power to define the multicultural kindergarten. When one mathematician notes that different cultures teach different numeric systems, he is offering one way to understand the Guidelines in STM, where it states that "students shall have knowledge about children's mathematic development from a multicultural perspective". In other words, the academic staff doesn't simply teach students in accordance with the national guidelines: content in the KTE is defined within particular contexts and must reflect sensitivity to the differences between national ideas and local realities. The academic staff is the link between the national guidelines and practical trainee kindergartens; these staff members should therefore be aware of their power to define the multicultural kindergarten.

It is legitimate to question the resource-orientated perspective in the Framework Plan and the Pamphlet, as Otterstad and Andersen (2012) do. BULL states that the students should "use cultural diversity as a resource" (Table 1), and one academic staff member 
writes that "cultural diversity is a resource". On the other hand, the informants in the kindergartens talk about concrete challenges. The KTE should manage to see cultural diversity as both a resource, as the Guidelines and academic staff do, and as the kind of challenge the kindergarten pedagogues experience.

What is included or not included in different contexts and discourses is of interest here. The interviews with kindergarten pedagogues in this study reinforce a view that a multicultural kindergarten is defined only in terms of the inclusion of minorities, in particular Muslim children. Given that Islam is the largest minority religion in Norway, it is striking (but perhaps not surprising) that in their responses to the survey, these kindergarten pedagogues did not take into consideration other cultures and religions. Strangely, Islam is not mentioned explicitly in the Framework Plan (2011), and the national guidelines make only general references to "other world religions"; the Guidelines have much to say about the Sámi, but nothing about other minorities. As a result of this lack of specifics about the context of the multicultural and multi-religious kindergarten, the academic staff members tasked with training future kindergarten teachers are left to discuss, define, and redefine their understanding of the multicultural in the kindergarten context. A multicultural kindergarten is more than one that includes Muslims and Sámi, and a nuanced definition of multicultural encompasses more than the representation of one minority group in the kindergarten. A multicultural kindergarten consists of individuals, majorities as well as minorities, with unlike languages, cultures, and worldviews. As Poulter et al. points out, educations "are always social, political and historical constructions" (2015, p. 11-12). The KTE guidelines are in essence premised on political assumptions.

\section{Conclusion}

The national guidelines address multicultural perspectives and cultural diversity as they apply in different fields of knowledge. There is a certain disconnect between how the Guidelines address multicultural issues and how pedagogues actually experience this within the kindergarten setting. Whereas the Guidelines are concerned with mathematics, reading and literature, diet, and so on, the kindergarten pedagogues talk about world conflicts and child-rearing issues as they relate to the cultures and/or religions of kindergarten children and their parents. Since the Guidelines state that in one of the fields of knowledge (BULL) it should be used as a resource perspective for pedagogic work in a diverse kindergarten, academic staff members are tasked with addressing the challenges and possible conflicts in a multicultural kindergarten. The Framework Plan outlines what multicultural perspectives entail, and these ideas must be interpreted and discussed by the academic staff with pedagogues in practical trainee kindergartens. Also, the academic field must be attentive to what pedagogues in kindergartens experience in their daily meetings with parents and children. There is a need to see the two contexts as connected: the realm of education, ideas, and discussions on the one hand and the reality of the actual kindergarten on the other. This study suggests that KTEs can do more to expand upon their discussions and definitions of the multicultural and multi-religious kindergarten and to address the challenges kindergarten pedagogues face in partnering with children and parents in these diverse settings.

Open Access This article is distributed under the terms of the Creative Commons Attribution 4.0 International License (http://creativecommons.org/licenses/by/4.0/), which permits unrestricted use, distribution, 
and reproduction in any medium, provided you give appropriate credit to the original author(s) and the source, provide a link to the Creative Commons license, and indicate if changes were made.

\section{References}

Aamotsbakken, B. (2010). Strukturalisme og tekstlingvistikk. I S. V. Knudsen \& B. Aamotsbakken (Red.), Teoretiske tilnarminger til pedagogiske tekster (s. 72-88). Kristiansand: Høyskoleforlaget.

Berry, J. W. (2013). Research on multiculturalism in Canada. International Journal of Intercultural Relations, 37(6), 663-675. doi:10.1016/j.ijintrel.2013.09.005.

Dervin, F. (2015). Towards post-intercultural teacher education: analysing 'extreme' intercultural dialogue to reconstruct interculturality. European Journal of Teacher Education, 38(1), 71-86. doi:10.1080/ 02619768.2014 .902441$.

Foucault, M. (1999) [1970]). Diskursens orden (L'ordre du Discours). Oslo: Spartacus Forlag.

Fylkesnes, S. (2011). "The Multicultural": Constructions in the curriculum of Norwegian primary schoolteacher education. (Master's thesis, Høgskolen i Oslo). Oslo: Høgskolen i Oslo.

Gjervan, M. (Red.). (2006). Temahefte om språklig og kulturelt mangfold (Pamphlet on linguistic and cultural diversity). Oslo: Kunnskapsdepartementet.

Karlsson, A.-M. (2010). I textanalysens utmarker? Om att intressera sig för vad texter gör (och hur de gör det). I. G. Byrman, A. Gustafsson \& H. Rahm (Red.), Svensson och svenskan. Med sinnen känsliga för språk (s. 162-174). Lund: Henrik Rahm.

Karlsson, A.-M. (2011). Online outdoor: Technological, discursive and textual transformations of the activity of skating. Human IT, 11 (1), pp. 103-138. http://etjanst.hb.se/bhs/ith/1-11/amk.pdf.

Karlsson, A.-M., \& Makkonen-Craig, H. (Eds.). (2014). Analysing text AND talk: Att analysera texter OCH samtal. Uppsala: Institutionen för nordiska språk.

Knudsen, S. V. (2010). Poststrukturalistiske tilgange. I S. V. Knudsen \& B. Aamotsbakken (Red.), Teoretiske tilnarminger til pedagogiske tekster (s. 152-176). Kristiansand: Høyskoleforlaget.

Knudsen, S. V., \& Aamotsbakken, B. (2010). Refleksioner over pædagogiske tekster. I S. V. Knudsen \& B. Aamotsbakken (Red.), Teoretiske tilnarminger til pedagogiske tekster (s. 13-32). Kristiansand: Høyskoleforlaget.

Krogstad, K. (2015). På leting etter religion. En diskursanalyse av begrepet « det flerkulturelle » i politiske tekster om barnehage. Norsk pedagogisk tidsskrift, 99 (1), s. 3-14. https://www-idunn-no.ezproxy.hit. no/npt/2015/01/paa_leting_etter_religion_-_en_diskursanalyse_av_begrepet_d.

Krogstad, K., \& Hidle, K. M. W. (2015). Høytidsmarkering i religiøst mangfoldige barnehager. Nordisk barnehageforskning, 9 (6), s. 1-17. https://journals.hioa.no/index.php/nbf/article/view/1007/1169.

Kunnskapsdepartementet (2012a). Nasjonal forskrift om rammeplan for barnehagelarerutdanning (Regulations for the national curriculum for kindergarten teacher education). https://www.regjeringen.no/ globalassets/upload/kd/rundskriv/2012/forskrift_rammeplan_barnehagelaererutdanning.pdf.

Kunnskapsdepartementet (2012b). Nasjonale retningslinjer for barnehagelarerutdanningen (National guidelines for the kindergarten teacher education). https://www.regjeringen.no/globalassets/upload/kd/ rundskriv/2012/nasjonale_retningslinjer_barnehagelaererutdanning.pdf.

Kunnskapsdepartementet (2013). Merknader til nasjonal forskrift om rammeplan for barnehagelaererutdanning (Remark on the regulations for the national curriculum for kindergarten teacher education). https://www.regjeringen.no/globalassets/upload/kd/rundskriv/2012/merknader_forskrift_rammeplan_ barnehagelaererutdanning.pdf.

Kuusisto, A., \& Lamminmäki-Vartia, S. (2012). Moral foundation of the kindergarten teacher's educational approach: Self-reflection facilitated educator response to pluralism in educational context. Special Issue on the Moral Core of Teaching, Education Research International, 1-13. http://dx.doi.org/10. $1155 / 2012 / 303565$.

MER (2011). Framework Plan for the content and tasks of kindergartens. Oslo: Ministry of Education and Research. http://www.udir.no/Upload/barnehage/Rammeplan/Framework_Plan_for_the_Content_and_ Tasks_of_Kindergartens_2011_rammeplan_engelsk.pdf?epslanguage=no.

Modood, T. (2007). Multiculturalism: A civic idea. Cambridge: Polity Press.

Otterstad, A. M., \& Andersen, C. E. (2012). “'Ressursorientert tilnærming til språklig og kulturelt mangfold": Diskursive lesninger av inkludering i barnehagen. Nordisk barnehageforskning, 5(2), 1-21.

Poulter, S., Riitaoja, A.-L., \& Kuusisto, A. (2015). Thinking multicultural education 'otherwise'-from a secularist construction towards a plurality of epistemologies and worldviews. Globalisation, Societies and Education,. doi:10.1080/14767724.2014.989964. 
Sagberg, S. (2003). Children's spiritual rights. In A. Gunnestad (Ed.), Children's rights in early childhood education in Africa and Norway. Trondheim: Queen Maud's College of Early Childhood Education.

Sagberg, S. (2011). Children as spiritual subjects and the significance of educational environments. In F. Kraft, H. Roose, \& G. Büttner (Eds.), Symmetrical communication? Philosophy and theology in classrooms across europe (pp. 113-132). Rehburg-Loccum: Religionspädagogisches Institut Loccum.

Sagberg, S. (2012). Education and nurture revisited in the light of spirituality. In T. van der Zee \& T. J. Lovat (Eds.), New perspectives on religious and spiritual education (pp. 197-214). Münster: Waxmann.

Sagberg, S. (2013). Religious education as culture education. Panorama: International Journal of Comparative Religious Education and Values, 25, pp. 79-87.

Schweitzer, F., \& Biesinger, A. (2015). Kulturell und religiös sensibel? Interreligiöse und Interkulturelle Kompetenz in der Ausbildung für den Elementarbereich. Münster: Waxmann.

Schweitzer, F., Edelbrock, A., \& Biesinger, A. (2011). Interreligiöse und interkulturelle Bildung in der Kita. Münster: Waxmann.

Statistics Norway (2014). Trus- og livssynssamfunn utanfor Den norske Kyrka, 1.januar 2014 (Religious communities and life stance communities, 1 January 2014). https://ssb.no/en/kultur-og-fritid/statistikker/ trosamf.

Statistics Norway (2015). Den norske kirke, 2014 (Church of Norway, 2014). https://ssb.no/kultur-og-fritid/ statistikker/kirke_kostra.

White Paper No. 6 (2012-2013) to the Storting (2012). A comprehensive integration policy. Diversity and community. https://www.regjeringen.no/globalassets/upload/bld/ima/integreringsmelding_mangfold_eng.pdf. 